\title{
FORMER HIEROMONK ILIODOR (TRUFANOV) \\ IN THE PLANS OF THE ALL-RUSSIAN EXTRAORDINARY COMMISSION TO SPLIT THE RANKS OF THE RUSSIAN ORTHODOX CHURCH (1919-1921) ${ }^{1}$
}

\author{
Mikhail Yu. Krapivin \\ Saint Petersburg State University, Saint Petersburg, Russian Federation
}

\begin{abstract}
Introduction. The paper is devoted to the issues of cooperation in 1919-1922 between the Soviet State security agencies and scandalous representative of the extreme right wing of the Orthodox clergy, former hieromonk Iliodor (S. M. Trufanov). Analysis of this plot will help supplement our ideas about the policy of the Soviet State in the religious issue during the Civil War. Materials and methods. The paper is based mainly on the unpublished documents stored in the Central Archive of the Federal Security Service of Russia and in the State Archives of the Volgograd Region. The system of research procedures used in the published work, based on historical-genetic, historical-systemic and concrete historical methods, enabled the author to convincingly reconstruct the plans of the chekists towards Iliodor. Analysis. In the autumn of 1919, it became obvious to the country's leadership that it would not be possible to ensure victory on the anti-religious front without direct interference by the All-Russian Extraordinary Commission (hereinafter - the Cheka) in the personnel policy of the Orthodox Russian Church. The variants of promotion to the leading church posts of those hierarchs who were ready to cooperate with the chekists were discussed. Results. Thus, the Soviet State sought to achieve the transformation of the Church into an institution controlled from the outside. However, in the future the Bolsheviks were not needed by Church, neither in the old nor in the updated form. That is why the Cheka intended to use Iliodor to destroy the unity of the ranks of the Orthodox Russian Church, but was not ready (even for the sake of achieving this goal) to seriously support his proposals to the creation of a "renewed people's church" and to the organization of a broad network of religious communes.

Key words: Orthodox Russian Church, Hieromonk Iliodor (S.M. Trufanov), Tsaritsyn, Secret Department of the All-Russian Extraordinary Commission, Council of People's Commissars of the RSFSR, V. I. Lenin.

Citation. Krapivin M.Yu. Former Hieromonk Iliodor (Trufanov) in the Plans of the All-Russian Extraordinary Commission to Split the Ranks of the Russian Orthodox Church (1919-1921). Vestnik Volgogradskogo gosudarstvennogo universiteta. Seriya 4, Istoriya. Regionovedenie. Mezhdunarodnye otnosheniya [Science Journal of Volgograd State University. History. Area Studies. International Relations], 2018, vol. 23, no. 6, pp. 76-93. (in Russian). DOI: https://doi.org/10.15688/jvolsu4.2018.6.5
\end{abstract}

УДК 94(47).084.3

ББК 63.3(2)61;67.401.212

Дата поступления статьи: 23.04.2018

Дата принятия статьи: 27.06.2018

\section{БЫВШИЙ ИЕРОМОНАХ ИЛИОДОР (ТРУФАНОВ) В ПЛАНАХ ВЧК ПО ВНЕСЕНИЮ РАСКОЛА В РЯДЫ ПРАВОСЛАВНОЙ РОССИЙСКОЙ ЦЕРКВИ (1919-1921 гГ.) ${ }^{1}$}

\section{Михаил Юрьевич Крапивин}

Санкт-Петербургский государственный университет, г. Санкт-Петербург, Российская Федерация

Аннотация. Статья посвящена деятельности Илиодора (Сергея Михайловича Труфанова (1880-1952)), знаковой фигуры в православной (околоправославной) и общественно-политической среде первой четверти XX века. В работе речь идет о «советском» периоде жизни бывшего (на тот момент) иеромонаха и о следе, 
который оставило в его судьбе сотрудничество с советскими органами государственной безопасности. На основе всех доступных на сегодняшний день документальных источников предпринята попытка выявить место и роль Илиодора в планах Секретного отдела Всероссийской Чрезвычайной Комиссии (СО ВЧК) по внесению раскола в ряды Православной Российской Церкви. С опорой на архивные материалы дана характеристика комплекса агентурно-оперативных мероприятий, применявшихся центральными и территориальными органами ЧК для достижения этой цели. Кроме того, реконструирована (в основных чертах) картина взаимоотношений С.М. Труфанова с местным (царицынским) духовенством, центральными и губернскими структурами исполнительной власти и окружавшим Илиодора гражданским населением.

В приложении к статье впервые публикуются (по подлинникам и с научным комментарием) извлечения (касающиеся Илиодора) из текста циркулярного письма ВЧК № 6 от 25 июля 1920 г. и письмо «патриарха» Илиодора на имя председателя Совета Народных Комиссаров РСФСР В.И. Ленина от 20 мая 1921 года.

Ключевые слова: Православная Российская Церковь, иеромонах Илиодор (С.М. Труфанов), Царицын, Секретный отдел Всероссийской Чрезвычайной Комиссии, Совет Народных Комиссаров РСФСР, В.И. Ленин.

Цитирование. Крапивин М. Ю. Бывший иеромонах Илиодор (Труфанов) в планах ВЧК по внесению раскола в ряды православной российской церкви (1919-1921 гг.) // Вестник Волгоградского государственного университета. Серия 4, История. Регионоведение. Международные отношения. - 2018. - Т. 23, № 6. C. 76-93. - DOI: https://doi.org/10.15688/jvolsu4.2018.6.5

Введение. Как известно, в первые послереволюционные годы взаимоотношения Советского государства с Православной Российской Церковью (далее - ПРЦ) характеризовались предельной ожесточенностью. Однако с помощью силовых приемов достичь реального снижения уровня религиозности населения большевикам не удалось, а напряженность во взаимоотношениях власти и крестьянских масс только усилилась. Для атеистически ориентированного руководства страны становилось все более очевидным, что добиться перелома на антирелигиозном фронте не удастся без нахождения возможностей прямого вмешательства богоборческого государства в повседневную жизнедеятельность Церкви. В этой связи особая нагрузка ложилась на органы ЧК, имевшие в своем багаже специальные методики достижения выше означенных специфических целей. Уже с конца 1919 г. Секретный отдел ВЧК (далее - СО ВЧК) приступает к поиску путей и средств влияния на кадровую политику ПРЦ. В первую очередь рассматривались варианты продвижения на руководящие церковные посты (вплоть до патриаршего) тех иерархов, которые выразили готовность (по материальным или карьеристским соображениям) сотрудничать с чекистами. Через них, используя механизмы церковной дисциплины, органы ЧК намерены были обеспечить контроль среди приходского духовенства и активных мирян. Одновременно планировалось запустить (в том числе посредством педалирования лич- ностных разногласий и активизации консервативных и обновленческих тенденций) процессы внутренней дестабилизации и последующего организационного развала исторически сложившегося церковного организма, ведущие к его постепенному дроблению на автономные объединения и общины, лишенные общего руководства и конкурирующие между собой. Противостояние канонического церковного центра и различных квазицерковных групп, течений, движений, должно было, с точки зрения чекистов, помочь взаимной дискредитации оппонентов / противников в глазах верующих и создать благоприятную почву для постепенного отхода масс населения от религии как таковой.

Среди первых «перебежчиков» из православного лагеря, готовых принять на себя роль разрушителей церковного единства и провозвестников церковного раскола, оказались и несколько скандально известных представителей крайне правого крыла православного духовенства, в том числе бывший иеромонах Илиодор.

Методы и материалы. Личности Илиодора (С.М. Труфанова) посвящено много литературы, касающейся преимущественно дореволюционных лет его жизни и деятельности. «Советский» период представлен всего лишь несколькими работами [26, с. 154-156, 180-182, 186-188, 207-208; 45, с. 166-168; и др.]. Главной среди них является небольшая, но весьма информативная статья О.Ю. Редькиной, опубликованная в 2000 году. Ольга Юрь- 
евна впервые высказала аргументированное предположение о поддержке, оказывавшейся Илиодору со стороны органов ЧК. Однако на тот момент в ее распоряжении не было архивных источников, подтверждающих эту гипотезу.

Об Илиодоре писал в 2011 г. и автор настоящей публикации [17]. Впрочем, за прошедшие 7 лет удалось выявить целый ряд принципиально важных документов, уточняющих наши представления и о политике советского государства в религиозном вопросе в годы гражданской войны, и о планах чекистов в отношении Илиодора.

Система исследовательских процедур, применявшихся в публикуемой работе, базировалась на историко-генетическом, историко-системном и конкретно-историческом методах, дала возможность автору в значительной степени приблизиться к воспроизведению реальной картины взаимоотношений бывшего иеромонаха Илиодора с органами исполнительной власти и секретными службами Сoветского государства.

Статья написана главным образом на основе документов секретного делопроизводства центрального аппарата ВЧК, хранящихся в Центральном архиве Федеральной службы безопасности России (Президиум ВЧК, Секретный и Информационный отделы ВЧК), и с привлечением материалов Царицынской губернской ЧК, отложившихся в Государственном архиве Волгоградской области (переписка с Царицынским губисполкомом, информационные сводки и бюллетени, направлявшиеся в Москву и Самару, Полномочному представителю ВЧК в Приволжском военном округе). В отдельных случаях использовались фонды Российского государственного архива социально-политической истории (для уточнения процесса подготовки и редактирования решений пленума Центрального комитета Российской коммунистической партии (большевиков) от 18 мая 1921 г.), а также Государственного архива Российской Федерации (для описания путей доставки в Москву письма C.M. Труфанова от 20 мая 1921 г., адресованного В.И. Ленину, и воспроизведения реакции сотрудников аппарата Совета Народных Комиссаров РСФСР на факт поступления письма «патриарха» Илиодора).
Анализ. Илиодор (Сергей Михайлович Труфанов (1880-1952)) родился в казачьей семье. В 1901 г. он окончил Донскую духовную семинарию и поступил в Санкт-Петербургскую духовную академию. 29 ноября 1903 г. принял монашество и был рукоположен во иеромонаха. В 1905 г. Труфанов окончил академию со степенью кандидата богословия. С 1905 г. он служил иеромонахом Почаевской Успенской лавры на Волыни. С 27 января 1908 г. илиодор был заведующим Свято-Духовским монастырским мужским подворьем г. Царицына и противосектантским миссионером Царицынского уезда Саратовской епархии. В этой должности он зарекомендовал себя как ярый националист, активный член Союза русского народа. Его проповеди были направлены против любых проявлений инакомыслия в культуре и общественно-политической жизни России, полны обличительных выпадов в адрес столыпинской бюрократии, дворянской и разночинской интеллигенции, иноверцев и революционеров. В 1909-1912 гг. Илиодор сблизился, а затем рассорился с Г. Распутиным. С течением времени иеромонах все чаще подчеркивал свои расхождения с церковными иерархами, обвиняя членов Священного синода в потворстве «святому чорту». В 1909 г. синодальным постановлением он был запрещен в священнослужении, но постановлению не подчинился. Однако несмотря на все это, его назначили настоятелем Новосильского Свято-Духова мужского монастыря Тульской епархии. С 10 февраля 1911 г. он вновь стал заведующим Свято-Духовским монастырским мужским подворьем г. Царицына. В январе 1912 г. его направили для послушания во Флорищеву пустынь Владимирской епархии. В октябре 1912 г. Илиодор заявил об отказе от православной веры. В конце 1912 г. постановлением Священного синода он был лишен сана и монашества и выслан под надзор полиции в одну из станиц Области Войска Донского. Собрав группу общинников, Илиодор провозглашает себя основателем новой религии «вечной истины», ратует за возвращение к языческим идеалам и обожествлению сил природы, отрицает христианские таинства и обряды, церковную иерархию, пренебрегает церковным браком. Начав с обличения светской и церковной администрации, доводит дело 
до логического завершения, объявляя, что «теперь я государя и государыню не признаю». После инспирированного Илиодором неудачного покушения на Г. Распутина, в 1914 г. он (при содействии М. Горького) бежит за границу. С 1916 г. проживает в США.

Возвратившись в Россию в начале $1918 \Gamma^{2}$, Илиодор на некоторое время поселяется в Царицыне. Однако постепенно разгоравшееся пламя гражданской войны заставляет его покинуть Поволжье. Побывав во второй половине сентября 1918 г. на Кубани (в частности, в Майкопе [19, с. 1-2]), он направился к отцу на Дон, где был арестован белогвардейцами и после непродолжительного пребывания в тюрьме Новочеркасска (октябрь ноябрь 1918 г.) выслан за пределы Области Войска Донского.

11 марта 1919 г. во время посещения г. Камышина Царицынской губернии Илиодор дает интервью корреспонденту местной советской газеты «Набат». Он заявляет о своих симпатиях к Октябрьской революции, обосновывая это тем обстоятельством, что «после февральской революции остались помещики, купцы, фабриканты и дворяне, еще пившие народную кровь». Высказавшись в поддержку процесса отделения церкви от государства, Илиодор выразил желание сотрудничать с Советской властью в деле разрушения старого мира и постройки нового, подчеркнув при этом, что надеется приложить свои силы на ниве народного образования [1, с. 3]. Пересказ «набатовской» публикации от 16 марта 1919 г. под красноречивым заголовком «Перекрасившийся Илиодор» 30 марта 1919 г. появляется на страницах московских «Известий ВЦИК» [27, с. 4].]

В том же 1919 г. Илиодор встречается в Кремле с председателем ВЦИКа М.И. Калининым ${ }^{3}$ для обсуждения вопроса «о важной религиозной реформе» $[47$, с. 286$]$.

Одновременно с бывшим иеромонахом устанавливают контакты сотрудники Секретного отдела (СО) ВЧК. В протоколе Президиума ВЧК за 1 апреля 1919 г. (п. 10) читаем: «О С.М. Труфинове (так в тексте. - М. К.). $<\ldots>$ Тов. Дзержинскому выяснить в центре, как лучше использовать» [42]. 8 мая 1919 г. из кассы ВЧК Труфанову выдают 200 рублей [46]. В середине ноября 1919 г. председатель Мос- ковского совета Л.Б. Каменев разрешает Илиодору приобрести (за счет средств Моссовета) комплект теплых вещей для него самого и членов его семьи общей стоимостью 11834 рублей $[29 ; 30 ; 31]$.

9 июля 1920 г. Илиодор подает в Секретно-оперативный отдел Царицынской губЧК собственноручно написанное заявление с изложением программы своей деятельности на ближайший период. 25 июля 1920 г. на места рассылается очередное (с 6-м порядковым номером) циркулярное письмо ВЧК, включавшее полный текст заявления Илиодора и соответствующие директивы для региональных и местных органов ЧК (см.: Док. № 1).

Как явствует из содержания письма председателя Царицынской губЧК на имя председателя Царицынского губисполкома (делопроизводственный № 225/с от $11^{4}$ сентября 1921 г.), «с самого начала появления Илиодора в Царицын[е Г]убчека своевременно и подробно информировала Секретный Отдел ВЧК. В этой информации изложены подробно планы и намерения последнего и дальнейшим наблюдением за деятельностью Илиодора руководит ВЧК через Царицынскую Губчека» [28].

В середине ноября 1920 г. царицынские чекисты сообщали в Москву: «Илиодор <...> в настоящее время находится в Царицыне и ведет подготовительную работу <...>. В данное время он занят оборудованием своего кабинета[,] назначенного для приема посетителей, для каковой цели нам пришлось выхлопотать разную мебель и др. предметы. $<\ldots>$ За его деятельностью зорко следим. Ваше отношение от 2-го ноября с/г за № 31295 получили 12-го ноября [,] приступаем к исполнению указанных в этом отношении мер. Наше местное городское духовенство к деятельности Илиодора относится враждебно» [7].

В середине января 1921 г. Царицынская губЧК констатировала, что «сознательная часть населения» считает Илиодора «карьеристом и прихвостнем. Среди несознательных масс населения он та[к ж]е не пользуется никаким авторитетом, даже вызывает недоверие, ввиду его слишком резких проповедей против духовенства и вообще н[ет]актичности в обращении с массами» [3]. 
В первых числах февраля 1921 г. Царицынская губЧК информирует СО ВЧК о том, что «Иллиодор задался целью совершить церковную революцию, то есть устройство обновленной христианской народной церкви и организацию религиозных коммун» [5].

Начиная с 24 апреля 1921 г. Илиодор, получив официальное разрешение Царицынской Губернской комиссии по отделению церкви от государства [44], неоднократно обращается к толпе с проповедями на Соборной площади и в других людных местах Царицына.

Не позднее 14 мая 1921 г. Илиодор, самочинно приняв архиерейский сан (так называемое «рукоположение миром» ${ }^{5}$ ), объявляет себя «Епископом Царицынским и патриархом всея Южныя России» (по другой версии: «Патриархом Царицынским и всея южныя России») и приступает к формированию собственной церковно-иерархической структуры «Российского Синода» из 12 своих приверженцев (рукоположенных таким же неканоническим способом) [13].

Тем временем, 18 мая 1921 г. в Москве состоялся пленум ЦК РКП (б), посвященный преимущественно религиозной тематике [40; 41]. Выступавший на нем в качестве основного докладчика секретарь ЦК Е. Ярославский заострил внимание собравшихся на попытках части духовенства «пойти на соглашение с Советской властью и создать советскую церковь» (пример Илиодора): «Надо дать директиву на места, чтобы ни в какой степени не обольщались такого рода подходом, не поддерживали его, так как нет никакого сомнения в том, что под этой новой формой церковь пытается отстоять себя, как государственную организацию. Но не следует и замалчивать[,] и прятать такие факты, а, наоборот, широко разъяснить их значение трудящимся массам» [50]. Вместе с тем, еще на стадии подготовки итоговых документов пленума по требованию В.И. Ленина из проекта постановления был исключен 10-й пункт, в котором говорилось: «Партия обращает внимание всех организаций РКП, что за последнее время были неоднократные попытки отдельных служителей культа создать новую организацию церкви, заключить союз церкви с советским государством. РКП ведет самую широкую решительную борьбу с такими попытками, разоб- лачает их реакционный смысл, эту новую попытку приспособить паразитический организм церкви к государственной организации. Факты подобного рода необходимо не замалчивать, а широко разъяснять[,] вместе с тем используя их, как новое доказательство силы и влияния пролетарской революции» $[18$, с. 440 , $721 ; 38$, л. 5; 39, л. 2-2 об.].

20 мая 1921 г. Илиодор письменно обращается к В. И. Ленину с предложением о сотрудничестве (см.: Док. № 2), но поддержки в Совнаркоме РСФСР, судя по всему, не находит.

В середине сентября 1921 г. царицынская губЧК информировала СО ВЧК, что «на предложение наше ехать в Москву Илиодор предъявил требование обеспечить его в дорогу всем необходимым и снабдить материалом на костюмы и только по получению всего этого он даст свое согласие на выезд. Такого рода требования рассматривались нами как ультиматум, основанный на самонадеянности и якобы его полезной деятельности для соввласти тогда как в действительности никакой существенной пользы и помощи от его деятельности не было. Поэтому на все его требования нами отвечено отказом. Он в свою очередь отказался выехать в Москву, но через полуторы две недели раздумал» [2]. 29 сентября Илиодор отправляется в столицу [4], однако пробыв в Москве непродолжительное время, той же осенью возвращается в Царицын.

Во второй половине ноября 1921 г., по свидетельству чекистов, «илиодоровское движение в массе постепенно укрепляется. Замечаются случаи, когда крестьянство целыми церковными приходами отрекаются от старого духовенства, не взирая на проклятия и отлучения от церкви епископом» [6]. При этом, «отношение духовенства к илиодоровскому движению прежнее. Всячески стараются оклеветать перед массами, но вместе с тем соблюдают в этом осторожность, полагая[,] что Илиодор работает с ведения Советской власти» [32].

Вместе с тем, в начале января 1922 г. Илиодор жалуется сотрудникам заграничных благотворительных организаций, прибывшим в Царицын («Американская Администрация Помощи» (AРА)), что советская власть «ему $<\ldots>$ не мешает, но не содействует и не считает его другом народа» [35]. Действитель- 
М.Ю. Крапивин. Бывший иеромонах Илиодор (Труфанов) в планах ВЧК по внесению раскола в ряды ПРЦ

но, как явствует из сводок Царицынской губЧК за вторую половину января - первую половину февраля 1922 г., против Илиодора «ведется разработка дела» с целью разоблачения «его истинной физиономии» человека, лишь прикрывавшегося «маской “религиозного коммуниста" и ревнителя за Соввласть» $[33 ; 34]$.

В мае 1922 г. Илиодор неожиданно для многих уезжает из Царицына [15]. Он покидает Россию навсегда, перебравшись с семьей первоначально на территорию Прибалтики, оттуда в Германию [11], а затем в США. После отъезда «патриарха» из Царицына илиодоровские «архиереи» постепенно самоликвидируются, принеся покаяние, и возвращаются к приходской деятельности. С марта 1929 г. прекращают легальное существование и местные группы последователей Илиодора [16; 20; 22; 25, с. 218, 220].

Результаты (выводы). Таким образом, Секретный отдел ВЧК планировал использовать Илиодора в качестве тарана, разбивающего единство рядов ПРЦ, но не готов был (даже ради достижения этой цели) сколько-нибудь серьезно поддерживать «церковную революцию» бывшего иеромонаха, предполагавшую создание параллельного центра церковной власти в лице «обновленной христианской народной церкви» и организацию сети «религиозных коммун». Попытки Илиодора сформировать собственную церковно-иерархическую структуру посредством так называемого «рукоположения миром» вряд ли могли (в силу своей неканоничности) быть приняты (одобрены) широкими массами верующих.

С зимы 1921/1922 г. меняется тактика органов ЧК в отношении Московской Патриархии: теперь ставка делается на договороспособную (с точки зрения чекистов) часть молодого приходского духовенства (проявлявшую недовольство господством в Церкви монашествующего епископата) в целях завоевания снизу, посредством многоходовых оперативных комбинаций, Высшего Церковного Управления Православной Российской Церкви [9; 10]. В новых планах чекистов Илиодору места уже не оставалось. 


\title{
ПРИЛОЖЕНИЕ
}

*№ 1

\section{Из циркулярного письма ВЧК № 6}

\section{5 июля 1920 г.}

\section{СОВЕРШЕННОСЕКРЕТНО.}

\author{
Экземпляр № ..... \\ для \\ Хранится за ответственностью \\ председателя или начальника как \\ ШИФР.
}

\author{
Циркулярное письмо ВЧК. \\ № 6 . \\ ОТ 25-ГО ИЮЛЯ 1920 ГОДА. \\ ВСЕМ ГУБЧРЕЗКОМАМ, ОСОБООТДЕЛАМ И РТЧК.
}

$<\ldots>$

\section{О духовенстве.}

Православная церковь трещит по всем швам. <..> Коммунизм исключает возможность существования религии. Они один другого исключают. Поэтому в нашу задачу отнюдь не входит способствовать укреплению хотя бы самой либеральной церкви. Мы е[е] должны разрушать ${ }^{6}$.

Но в этом процессе мы должны использовать существующие в церковной жизни и враждующие между собою элементы, чтобы они сами один другого уничтожали. В этих целях мы иногда должны поддержать то или другое течение, менее для нас вредное, оказывая е[му] даже материальную поддержку, как это нами было указано в предыдущих циркулярных письмах ${ }^{7}$.

Останавливаясь в данном случае на заявлении Иллиодора, Секретный отдел ВЧК указыва[е]т, что его начинания должны быть поддержаны Чр[езвычайными] Ком[мисиями], конечно не в целях создания религиозных коммун, а разоблачения церкви и е[е] служителей.

\section{Программа деятельности Иллиодора.}

1. Единственный путь примирить русскую народную массу с политическою коммуною есть коммуна (община) религиозная ${ }^{8}$.

В политическую коммуну русский народ может вступить только через общину религиозную.

П[ов]ести русский народ в религиозную общину можно только через церковную революцию. Так называемая православная русская церковь должна быть разрушена религиозною церковн[о]ю революции[ей].

Я, Иллиодор, желаю отдать все свои силы, все свое разумение именно этой революции.

Для выполнения этой задачи я желал бы предпринять пешком с евангелием и посохом в руках в одежде Иисуса Христа апостольское путешествие по обоим берегам Волги от Цариц[ы]на и до Николаевска и о[б]ратно от Камышина до Цариц[ы]на; из Цариц[ы]на по обоим берегам Дона от Калача и до Ростова через Новочеркасск и обра[т]но через Новороссийск, Екатеринодар и по линии железной дороги от ст[анции] «Тихорецкая» и до Цариц[ы]на 9 .

Во время этих путешествий я во всех попутных городах, селах, станицах, слободах и хуторах намерен проповед[о]вать следующее:

1. Сейчас главным жупелом в руках духовен[с]тва, этого слепого вожд[я] слепых народных масс, является запугивание народа антихристом, который мерещится ему, духовенству, в лице чуть не каждого представителя Советской власти; я на основан[и]и церковно-исторических данных и истинного понимания учения Иисуса Христа докажу и покажу, что настоящим и подлинным антихристом (противником учения Иисуса Христа) является всегда и теперь является именно духовенство, как так называемой православной церкви, так и духовенство других христианских религий. 
2. Душою всего учения Христа является устройство общи[нн]ой жизни людей на принципах свободы[,] братс[т]ва и равенства. Без общины или коммун[ы у]чение Иисуса Христа в жизни не исполнимо. И оно не исполнялось никем: ни духовенством, ни народом. Попытка апостолов устроить коммуну была погребена антихристами, преимущественно духовенством и царями.

3. Необходимо, в целях устроить религиозную общину, перевернуть в так называемой православной церкви все вверх дном, но делать это нужно постепенно. Сначала нужно в старые слова складывать новы[е] понятия, согласные с здравым разумом, а потом уже изменить и с[ам]ыя понят[и]я и даже отказываться от некоторых из них.

4. Между религиозно-православною общиною и политическою коммуною есть много сходства, но и много существенной разницы. Нужн[о] всякую точку соприкосновения уяснить, запечатлевать в сознании верующего народа, а всякое различие стушевывать[,] прим[и]рять с сознанием народным и, так или иначе, избегать разлада с народною властью[,] которая стреми[тс]я к тому же к чему и религиозными путями должны привести к одному месту, к центру, к земному счастью людей и народов.

5. Под[р]обное уяснение народу красоты общинной жизни. Ознакомление его с порядками общинной жизни. Доказательства непрерывности единой жизни: земной и загробной. Выяснение верующим той абсолютной истины, что в загробной жизни будут блаженство[в]ать только те[,] кто в земной жизни был достойным участником общи[нн]ой жизни.

6. Самый колкий вопрос настоящего времени - вопрос о военной службе, я согласно своих твердых убеждений, буд[у] в своих проповедях разрешать согласно со всеми мероприятиями Советской власти в военном деле. Хотя я и буду настоятельно указывать на слова Христа «н[е] убий», любите врагов ваших, но в то же время я буду доказывать, что эта заповедь, как и другие заветы Христа, исполнимы только в общинной жизни, а пока люди живут о[тд]ельно, как волки по норам, они должны убивать друг друга и это зло считать справедливым возмездием за то, что они не п[ос]лушали лучших людей мира и Иисуса Христа и не желали по[-]братски общиною (так в тексте. $-M . K$.).

1920 г. июля 9 дня.

\section{Сергей Михайлович Труфанов.}

Желаю послужить народу не ради материального прибытка или угождения кому бы то ни было, а ради истины и потому, что так поступить повел[е]вает мне моя совесть. Народный комиссар просвещения - А. В. Луначарский в прошлом году желал, чтобы я занимал[с]я в Москве литературным трудом. Желание его я исполнить не мог, потому, что был выбит из колеи жизни продолжительною болезн[ь]ю ${ }^{10}$ и потому, что дело, предложенное им мне, есть дело мертвое, а я ищу живого дела и за него готов отдать и жизнь свою. Иллиодор.

С подлинным верно:

Зам[еститель] Зав[едующего] Секретно-оператив[н]ым отделом

Царгубчека Богословский ${ }^{11}$.

$<\ldots>$

Настоящее циркулярное письмо должно быть вручено каждому уполномоченному, его помощнику в Губчека и РТЧК и переслано по одному экз[емпляру] на каждое политбюро и отделени[е] РТЧК.

Принять письмо не только в сведению[,] но и к неуклонному исполнению.

$<\ldots>$

* Центральный архив ФСБ России. - Ф. 1. - Оп. 4. - Д. 155. - Л. 46-76. Типографский оттиск. Раздел «О духовенстве» (Л. 65); раздел «Программа деятельности Иллиодора» (Л. 65-66).

Там же. - Ф. 66. - Оп. 1. - Д. 194а. - Л. 82-111. Типографский оттиск. Раздел «О духовенстве» (Л. 100); раздел «Программа деятельности Иллиодора» (Л. 100-101). 
*№ 2

\author{
Письмо С.М. Труфанова («Патриарха Илиодора») \\ на имя председателя Совнаркома РСФСР В.И. Ленина ${ }^{12}$
}

\title{
20 мая 1921 г.
}

\section{1. Мая 20 дня}

Глубокоуважаемый товарищ-брат Владимир Ильич!

С тех пор, как я вышел из рядов поповмракобесов, [я в] течение девяти ле[т м]ечтал о церковной революции. В нынешнем году (на Пасху) церковная революция началась в Царицыне.

Народ, осуществляя свои державные права, избрал и поставил меня патриархом Живой Христовой Церкви. Но дело пошло не так, как я предполагал, ибо оно начато не так, как должно...

Революция началась без санкции Центральной Советской Власти.

Чтобы поправить дело и двинуть его по более правильному и надежному пути, я обращаюсь к Вам и кратко выясняю следующее: церковная революция имеет целью разрушить поповское царство, отнять у народных масс искаженное христианство и утвердить их религиозное сознание на основах истинного христианства, или религии человечности. А все эти достижения церковной Революции должны привести к одному: к примирению народных масс с коммунистическим устройством жизни.

Вести Русскую массу к политической коммуне нужно через религиозную общину. Другими путями идти будет слишком болезненно.

Как Вы, Владимир Ильич, смотрите на это. Признает[е л]и В[ы к]акое значение за Церковной Революцией в деле достижения русским народом идеалов Социальной Революции? Если Вы интересуетесь затронутым мною вопросом, то не нужн[о л]и будет приехать мне к Вам в Москву и лично побеседовать с Вами об этом, по моему мнению, весьма важном деле?

Прошу Вас ответить мне и написать мне краткое письмо о своем желании видеть меня и говорить со мною о церковной Русской революции.

Остаюсь преданный Вам, Ваш брат товарищ, гражданин

Сергей Михайлович Труфанов (Патриарх Илиодор) ${ }^{13}$.

* Государственный архив Российской Федерации. - Ф. Р-130. - Оп. 5. - Д. 1030. - Л. 5-5 об. Рукописный подлинник. Автограф С. М. Труфанова. Штамп вх. документации Приемной СНК, заполненный от руки: № 5404 от 16 июня 1921 г. Рукописная помета: «Снять копию».

Государственный архив Волгоградской области (ГАВО). - Ф. Р-37. - Оп. 2. - Д. 10. - Л. 54. Заверенная машинописная копия с копии, датированная днем поступления письма в Приемную Совнаркома: «16/VI-21 г. вход. № 5404». Заверительная надпись - автограф. Круглая печать VIII отдела Наркомюста РСФСР.

Опубликовано по копии с копии из ГАВО с неточным архивным шифром, неверной датировкой и пропусками в тексте «Вести русскую массу к политической общине нужно через религиозную общину»: Письмо иеромонаха Илиодора В. И. Ленину / вст. ст., коммент. и подг. текста к публ. Е. В. Булюлиной, И. В. Гарсковой // Отечественные архивы. - 2005. - № 4. - С. 115-119 [Письмо С. М. Труфанова (Илиодора) председателю СНК РСФСР В. И. Ленину с предложением о сотрудничестве. 16 июня 1921 г. со ссылкой на: ГАВО. - Ф. Р-37. - Оп. 2. - Д. 10. - Л. 54-54 об.]. 


\section{ПРИМЕЧАНИЯ}

${ }^{1}$ Публикация подготовлена при финансовой поддержке РФФИ в рамках научного проекта № 18-09-00299 A.

${ }^{2}$ Не позднее 10 (23) апреля 1918 г. [21, с. 171].

${ }^{3}$ О встрече с М.И. Калининым Илиодор упоминал в интервью, опубликованном в 1934 г. на страницах русскоязычной газеты «Наша речь», выходившей на территории Румынии [8]. но: 14.

${ }^{4}$ Вторая цифра читается неуверенно, возмож-

${ }_{5}^{5}$ Речь идет о существовавшей у ранних христиан практике полагать кандидатов во епископа руками мирян и пресвитеров (апостольскую преемственность, таким образом, сберегала и передавала вся Церковь). В процедуре рукоположения Илиодора принимали участие священники, диаконы и миряне, что рассматривалось Московской Патриархией, как недопустимое (пусть даже оправданное историческими прецедентами) нарушение канонических правил возведения в епископский сан.

6 Язык и стилистика документа определенно свидетельствуют, что его авторство принадлежит Мартыну (Мартину, Яну) Ивановичу (Пиндриковичу, Фридриховичу) Лацису (Судрабсу) (18881938), на момент описываемых событий заведующему Секретным отделом ВЧК (начало января 1919 г. - середина марта 1919 г.; середина сентября 1919 - 6 сентября 1920 г.).

${ }^{7}$ Речь идет о циркулярно-информационном письме ВЧК № 3 от 1 января 1920 года [49].

${ }^{8}$ Идея создания земледельческой коммуны возникла у Илиодора еще в дореволюционные годы, в июне 1918 г. он вновь вернулся к ней. Сельскохозяйственный коллектив коммунального типа, который планировалось организовать на базе Свято-Духовского монастыря, должен был объединить около 100 семей, работавших на земле [36; 48]. Однако воплотить в жизнь свой замысел Илиодору удалось лишь в апреле 1921 года. В состав общины-коммуны «Вечный мир» вошли 6 крестьянских семей, переселившиеся из Николаевского уезда, к ним присоединились последователи бывшего иеромонаха из числа городских жителей [24; 43, с. 111; 45, с. 167]. Коммуна копировала устройство ранней христианской общины («первоначальной апостольской живой церкви Христа»), в которой все верующие равны («коммунальный труд и собственность»), а богослужение максимально упрощено (вплоть до отрицания необходимости икон).

${ }^{9}$ «Иллиодор. < ..> последние месяцы зимы он уделяет на знакомство с сущностью имеющихся в данное время религиозных коммун и чтобы подготовить почву к весеннему походу. Последнее время он поехал по известным ему религиозным об- щинам[,] расположенным по селам на берегу реки Волги» [5].

10 «Тов. А.В. Луначарский в апреле месяце этого года оставил меня в Москве и дал мне литературную работу. Июль, август, сентябрь и половину октября я лежал в постели: был болен дважды тифом» [30, л. 51-51 об.].

${ }^{11}$ Богословский Иван Митрофанович заместитель заведующего Секретно-оперативным отделом (СОО) Царицынской губЧК (по сведениям на июль 1920 г. и первую половину октября 1920 г.); начальник Секретно-оперативной части (СОЧ) Царицынской губЧК (по сведениям на первую половину сентября 1921 г.); заместитель председателя Царицынской губЧК (по сведениям на вторую половину сентября и вторую половину декабря 1921 г.).

12 Письмо в Приемную Совнаркома РСФСР было передано с оказией: «Москва, 15/VI-21 год. Дорогой, родной тов. Ленин! Простите, может быть[,] я делаю глупость, отнимая у Вас время иллиодоровским письмом. Но меня упросили передать. Если Вам понадоби[т]ся ответить Иллиодору, то адрес мой: Малая Дмитровка, 6. Ком[мунистический] Ун[иверсите]т [имени] Свердлова. Курсантке В. Рукавцовой. А я передам Ваше письмо гражданке, приехавшей из Царицына. С коммунистическим приветом - В. Рукавцова» [14].

134 августа 1921 г. письмо Илиодора было препровождено (делопроизводственный № 5404) из Приемной Совнаркома РСФСР заместителю управделами Совнаркома РСФСР В.А. Смольянинову («на Ваше усмотрение»). 11 августа 1921 г. тот, в свою очередь, распорядился отослать копию письма в ВЧК и запросить Царицынский губисполком о деятельности Илиодора [37]. 14 августа 1921 г. с письма Илиодора была снята заверенная машинописная копия и 15 августа Секретарь Управделами СНК и СТО направил (делопроизводственный № 10630) соответствующий запрос в Царицын [12; 23]. Ознакомился ли с письмом Илиодора В.И. Ленин, нам установить, к сожалению, не удалось.

\section{СПИСОК ЛИТЕРАТУРЫ}

1. Беседа с Иллиодором // Набат (орган Камышинского (Царицынской губ.) Совета рабочих, крестьянских, казачьих и красноармейских депутатов). - 1919. - 16 марта (№ 30).

2. В Секретный отдел (СО) ВЧК. Информационный бюллетень № 17. О положении в губернии и деятельности Царицынской губЧК за период с 1-го по 15-е сентября 1921 г. Разделы «Духовенство» и «Илиодор» // Государственный архив Волгоградской области (ГАВО). - Ф. Р-37. - Оп. 2. - Д. 9. Л. 11 об. 
3. В СО ВЧК. Сводка № 1. Двухнедельная информационная сводка Царицынской Губернской Чрезвычайной Комиссии о положение и своей деятельности в губернии за время с 1-го по 15-е января 1921 г. Раздел «Илиодор» // Центральный архив Федеральной службы безопасности России (ЦА ФСБ России). - Ф. 1. - Оп. 5. - Д. 390. - Л. 115-115 об.

4. В СО ВЧК. Сводка № 18. Двухнедельная информационная сводка Царицынской губЧК о положении и своей деятельности в губернии за время с 15-го по 30-е сентября 1921 г. Раздел «Илиодор» // ГАВО. - Ф. Р-37. - Оп. 2. - Д. 9. - Л. 15.

5. В СО ВЧК. Сводка № 2. Двухнедельная информационная сводка Царицынской Губернской Чрезвычайной Комиссии о положение и своей деятельности в губернии за время с 15-го по 31-е января 1921 г. Раздел «Иллиодор» // ЦА ФСБ России. Ф. 1. - Оп. 5. - Д. 390. - Л. 111.

6. В СО ВЧК. Сводка № 20. Двухнедельная информационная сводка Царицынской губЧК о положении и своей деятельности в губернии за время с 15-го по 30-е ноября 1921 г. Раздел «Илиодор» // ГАВО. - Ф. Р-37. - Оп. 2. - Д. 12. - Л. 94.

7. В СО ВЧК. Сводка № 22. Двухнедельная информационная сводка Царицынской ГубЧК о положение и своей деятельности в губернии за время с 1-го по 15-е ноября 1920 г. Раздел «Духовенство» // ЦА ФСБ России. - Ф. 1. - Оп. 4. - Д. 241. Л. 49 об. -50.

8. Гольцев, Е. «Революционер справа». История иеромонаха Илиодора / Е. Гольцев // Неделя (Москва). - 1990. - № 26. - С. 10.

9. Докладная записка бывшего заведующего СО ВЧК М. И. Лациса на имя председателя ВЧК Ф. Э. Дзержинского от [3-4 декабря 1920 г.] о политике ВЧК в религиозном вопросе // ЦА ФСБ России. - Д. Р-33149. - Л. 71-72.

10. Докладная записка заведующего СО ВЧК Т. П. Самсонова на имя председателя ВЧК Ф. Э. Дзержинского от 4 декабря 1920 г. о политике ВЧК в религиозном вопросе // Российский государственный архив социально-политической истории (РГАСПИ). Ф. 76. -Оп. 3. - Д. 196. - Л. 4-4 об.

11. Жив курилка // Борьба (орган Царицынского губкома РКП (б) и губисполкома). - 1923. 21 февр.

12. Заверенная машинописная копия письма Илиодора, снятая 14 августа 1921 г. // Государственный архив Российской Федерации (ГАРФ). Ф. Р-130. - Оп. 5. - Д. 1030. - Л. 6.

13. Записи текстов выступлений Илиодора (Царицын, 24 апреля, 1 июня, 19 августа 1921 г.) // ГАРФ.Ф. А-353. -Оп. 4. - Д. 399. - Л. 21 об., 24, 32 об. - 33.

14. Записка курсантки Коммунистического унта им. Я. М. Свердлова В. Рукавцовой на имя В. И. Ленина от 15 июня 1921 г. с информацией о том, что она передала в Приемную Совнаркома РСФСР письмо Илиодора и ожидает ответа (если таковой будет) // ГАРФ. - Ф. Р-130. - Оп. 5. - Д. 1030. - Л. 3.

15. Изъятие и духовенство // Борьба (орган Царицынского губкома РКП (б) и губисполкома). 1922. - 10 мая.

16. Илиодоровщина // Борьба (орган Сталинградского губкома ВКП (б) и губисполкома). - 1928. 30 сент.

17. Крапивин, М. Ю. Деятельность С. М. Труфанова (бывшего иеромонаха Илиодора) в Советской России (1918-1922 гг.) в связи с формированием государственной политики в отношении Православной Церкви // Вестник церковной истории (Москва). - 2011. - № 1/2 (21/22). - С. 137-159.

18. Ленин, В. И. Предложения к проекту постановления Пленума ЦК РКП (б) о пункте 13 программы партии (18 мая 1921 г.) / В. И. Ленин // Полное собрание сочинений : в 55 т. - Изд. 5-е. - М. : Политиздат, 1970. - Т. 54 : Письма. Ноябрь 1921 март 1923. - XVI, $863 \mathrm{c}$.

19. Майкопская драма // Коммунист (орган Череповецкого губисполкома и губкома РКП (б)). 1919. - 27 апр. (№ 58).

20. Наследие Илиодора // Борьба (орган Царицынского губкома РКП (б) и губисполкома). 1922. -30 сент.

21. Окунев, Н. П. Дневник москвича [19171924 гг.]. В 2 кн. Кн. 1. 1917-1920 / Н. П. Окунев. М. : Военное изд-во, 1997. -319 с.

22. Оставим богов без жилплощади // Борьба (орган Сталинградского губкома ВКП (б) и губисполкома). - 1929. - 24 марта.

23. Отношение секретаря Управделами Совнаркома РСФСР в Царицынский губисполком № 10630 от 15 августа 1921 г. с просьбой «сообщить о деятельности Иллиодора в Царицыне» // ГАРФ. Ф. Р-130. - Оп. 5. - Д. 1030. - Л. 2.

24. Отношение Царицынской губернской комиссии по отделению церкви от государства в VIII отдел Наркомюста РСФСР № 32 от 28 апреля 1921 г. с просьбой дать руководящие указания по сути ходатайства «Христианского православного коллектива при монастырском Святодуховском храме г. Царицына» о предоставлении им в пользование монастырского храма и трех комнат в монастырском здании для организации религиозной социальной коммуны // ГАРФ. - Ф. А-353. - Оп. 5. Д. 237. - Л. 64, 66-66 об.

25. Отчет Сталинградского городского совета Союза воинствующих безбожников о проделанной работе с 15 января по 20 октября 1931 г. // Государство и религиозные организации Нижней Волги и Дона в XX веке : сб. док. и материалов ; кат. культ. зданий / сост. О. Ю. Редькина, Т. А. Савина. - Волгоград : Издатель, 2002. - Док. № 72. - С. 212-221. 
26. Очерки по истории Волгоградской епархии Русской Православной Церкви. - Волгоград : Издатель, 2003. -368 с.

27. Перекрасившийся Илиодор // Известия ВЦИК. - 1919. - 30 марта (№ 69).

28. Письмо председателя Царицынской губЧК Карла Поги на имя председателя Царицынского губисполкома И. М. Морозова № 225/с от 11 (или 14) сентября 1921 г. с характеристикой илиодоровского движения // ГАВО. - Ф. Р-37. - Оп. 2. - Д. 10. - Л. 50.

29. Письмо С. М. Труфанова председателю Моссовета Л. Б. Каменеву от 8 ноября 1919 г. с просьбой компенсировать стоимость одежды и предметов быта, отобранных у его семьи «представителями Советской Власти» в Царицыне в октябре - ноябре 1918 г. // Российский государственный архив социально-политической истории (РГАСПИ). - Ф. 323. - Оп. 2. - Д. 164. - Л. 52-53 об.

30. Письмо С. М. Труфанова [председателю Моссовета Л. Б. Каменеву] от 5 ноября 1919 г. с просьбой помочь приобрести комплект теплой одежды для него самого и членов его семьи // РГАСПИ. Ф. 323. - Оп. 2. - Д. 164. - Л. 50-51 об.

31. Письмо С. М. Труфанова в Президиум Моссовета от 14 ноября 1919 г. с просьбой оплатить счета на общую сумму 11834 руб. 85 коп. за приобретенные им носильные вещи // РГАСПИ. Ф. 323. - Оп. 2. - Д. 164. - Л. 54.

32. Полномочному представителю ВЧК [в] Приволжском военном округе (ПРИВО). Сводка № 21. Двухнедельная информационная сводка Царицынской губЧК о положении и своей деятельности в губернии за время с 16-го ноября по 1-е декабря 1921 г. Раздел «Духовенство» // ГАВО. - Ф. Р-37. Оп. 2. - Д. 12. - Л. 108.

33. Полномочному представителю ВЧК [в] ПРИВО. Бюллетень № 3. Двухнедельный информационный бюллетень Царицынской губЧК о положении и своей деятельности в губернии за время с 1-го по 15-е февраля 1922 г. Раздел «Духовенство» // ГАВО. - Ф. Р-37. - ОП. 2. - Д. 18. - Л. 65.

34. Полномочному представителю ВЧК [в] ПРИВО. Бюллетень № 2. Двухнедельный информационный бюллетень Царицынской губЧК о положении и своей деятельности в губернии за время с 15го по 31-е января 1922 г. Раздел «Иллиодор» // ЦА ФСБ России. - Ф. 1. - Оп. 6. - Д. 660. - Л. 52-52 об.

35. Полномочному представителю ВЧК [в] ПРИВО. Бюллетень № 1. Двухнедельный информационный бюллетень Царицынской губЧК о положении и своей деятельности в губернии за время с 1-го по 15-е января 1922 г. Раздел «Духовенство» // ЦА ФСБ России. - Ф. 1. - ОП. 6. - Д. 660. - Л. 49.

36. Постановление Святейшего Патриарха и Священного Синода Православной Российской Церкви от 12/25 июля 1918 г. по рапорту общего благо- чиннического собрания Царицынского округа Саратовской епархии об опасности захвата Сергеем Труфановым (при содействии местного совета) Свято-Духовского монастыря с целью создания в нем коммунистической общины // Российский государственный исторический архив. - Ф. 831. Оп. 1. - Д. 6. - Л. 62.

37. Препроводительное письмо № 5404 от 4 августа 1921 г. (к пересылаемому письму Илиодора) за подписью заведующего приемной Совнаркома РСФСР на имя Управделами Совнаркома РСФСР В. А. Смольянинова // ГАРФ. - Ф. Р-130. - Оп. 5. Д. $1030 .-$ Л. 4.

38. Проект постановления «Пленума Ц.К. Р.К.П. по вопросу об отношении к нарушениям п. 13 программы и постановке антирелигиозной пропаганды», подготовленный секретарем ЦК Ем. Ярославским // РГАСПИ. - Ф. 89. - Оп. 4. - Д. 127. - Л. 1-6.

39. Проект постановления «Пленума Ц.К. Р.К.П. по вопросу об отношении к нарушениям п. 13 программы и постановке антирелигиозной пропаганды», с пометами В. И. Ленина (18 мая 1921 г.) // РГАСПИ. - Ф. 2. - Оп. 1. - Д. 18763. - Л. 1-2 об.

40. Протокол заседания Оргбюро ЦК РКП (б) № 71 от 26 сентября 1921 г. П. 7. Утверждение постановления Пленума ЦК РКП (б) по вопросу о нарушениях пункта 13 программы и о постановке антирелигиозной пропаганды // РГАСПИ. - Ф. 17. Оп. 112. - Д. 310. - Л. 15.

41. Протоколы заседания пленума ЦК РКП (б) от 18 мая 1921 г. П. 7. О проведении в жизнь П. 13 программы партии (об отношении партии к членам РКП, выполняющим церковные обряды) // РГАСПИ. Ф. 17.-Оп. 2.-Д. 65. -Л. 1, 9, 17, 20-20 об.

42. Протокол заседания Президиума ВЧК от 1 апреля 1919 г. П. 10 // ЦА ФСБ России. - Ф. 1 ос. Оп. 3. - Д. 3. - Л. 4 об.

43. Протокол № 6 заседания Царицынской губернской комиссии по отделению церкви от государства с представителями губЧК и Жилищного отдела Царицынского губисполкома от 10 апреля 1921 г. П. 5. Заявление «Христианского православного коллектива» при монастырском Святодуховском храме г. Царицына с просьбой предоставить им в пользование монастырский храм и три комнаты в монастырском здании для организации религиозной социальной коммуны // Государство и религиозные организации Нижней Волги и Дона в XX веке / под ред. О. Ю. Редькиной, Т. А. Савиной. Волгоград : Издатель, 2002. - Док. № 19. - С. 111-112.

44. Протокол № 9 экстренного заседания Царицынской губернской комиссии по отделению церкви от государства от 23 апреля 1921 г. П. 1. «Письменное заявление иеромонах[а] Илиодора» о предоставлении ему возможности публичного выступления // ГАВО. - Ф. Р-122. - Оп. 1. - Д. 544. - Л. 37-37 об. 
45. Редькина, О. Ю. Илиодор в Советской России: 1918-1922 гг. / О. Ю. Редькина // Стрежень: научный ежегодник. - Волгоград : Издатель, 2000. Вып. 1.-С. 164-169.

46. Собственноручные записи председателя ВЧК Ф. Э. Дзержинского о выдаче денежных сумм на специальные расходы («Касса к 17/Х 1919 г.») // РГАСПИ. - Ф. 76. - ОП. 3. - Д. 73. - Л. 1.

47. Ферро, М. Николай II / М. Ферро. - М. : Международные отношения, 1991. - 350 с.

48. Ходатайство группы граждан - последователей С. М. Труфанова в Царицынский совет рабочих, солдатских, крестьянских и казачьих депутатов от 3 июня 1918 г. с просьбой предоставить здания Свято-Духовского монастыря для организации земледельческой коммуны на религиозных началах // ГАВО. - Ф. Р-71. - Оп. 1. - Д. 144. - Л. 12-14 об.

49. Циркулярно-информационное письмо ВЧК № 3 от 1 января 1920 г. Раздел «В чем должна состоять наша работа по части духовенства» // ЦА ФСБ России. - Ф. 1. - Оп. 4. - Д. 155. - Л. 10-10 об.

50. Ярославский, Е. Доклад на заседании Пленума ЦК РКП (б) от 18 мая 1921 г. по вопросу о нарушениях пункта 13 программы и о постановке антирелигиозной пропаганды / Е. Ярославский // Вестник агитации и пропаганды (Москва). 1921. - 15 сент. (№ 19). - С. 26-28.

\section{REFERENCES}

1. Beseda s Illiodorom [Interview with Illidore]. Nabat (organ Kamyshinskogo (Tsaritsynskoy gub.) Soveta rabochikh, krestyanskikh, kazachyikh $i$ krasnoarmeyskikh deputatov) [Nabat (Body of the Kamyshinsky (Tsaritsyn Province) Council of Workers, Peasants, Cossack and Red Army Deputies)], 1919, no. 30, 16 March.

2. V Sekretnyy otdel (SO) VChK. Informatsionnyy byulleten № 17 . O polozhenii v gubernii i deyatelnosti Tsaritsynskoy gubChK za period s 1-go po 15 -e sentyabrya 1921 g. Razdely «Dukhovenstvo» $\mathrm{i}$ «Iliodor» [To the Secret Department of the All-Russian Extraordinary Commission. Information Bulletin No. 17. On the Situation in the Province and the Activities of the Tsaritsyn Provincial Extraordinary Commission for the Period from September $1^{\text {st }}$ to $15^{\text {th }}$, 1921. Sections 'Clergy' and 'Iliodor']. Gosudarstvennyy arkhiv Volgogradskoy oblasti [State Archive of the Volgograd Region], F. R-37, Op. 2, D. 9, 1. 11.

3. V SO VChK. Svodka № 1. Dvukhnedelnaya informatsionnaya svodka Tsaritsynskoy gubChK o polozhenii i svoey deyatelnosti v gubernii za vremya s 1-go po 15-e yanvarya 1921 g. Razdel «Iliodor» [To the Secret Department of the All-Russian Extraordinary Commission. Report No. 1. Two-Week Information
Report of the Tsaritsyn Provincial Extraordinary Commission on the Situation and Activities in the Province during the Period from January $1^{\text {st }}$ to $15^{\text {th }}$, 1921. Section 'Iliodor']. Tsentralnyy arkhiv Federalnoy sluzhby bezopasnosti Rossii [Central Archive of the Federal Security Service of Russia], F. 1, Op. 5, D. 390, 11. 115-115.

4. V SO VChK. Svodka № 18. Dvukhnedelnaya informatsionnaya svodka Tsaritsynskoy gubChK o polozhenii i svoey deyatelnosti $v$ gubernii za vremya $\mathrm{s}$ 15-go po 30-e sentyabrya $1921 \mathrm{~g}$. Razdel «Iliodor» [To the Secret Department of the All-Russian Extraordinary Commission. Report No. 18. Two-Week Information Report of the Tsaritsyn Provincial Extraordinary Commission on the Situation and Activities in the Province during the Period from September $15^{\text {th }}$ to $30^{\text {th }}$, 1921. Section 'Iliodor']. Gosudarstvennyy arkhiv Volgogradskoy oblasti [State Archive of the Volgograd Region], F. R-37, Op. 2, D. 9, 1. 15.

5. V SO VChK. Svodka № 2. Dvukhnedelnaya informatsionnaya svodka TSaritsynskoy Gubernskoy Chrezvychaynoy Komissii o polozhenii i svoey deyatelnosti v gubernii za vremya s 15 -go po 31 -e yanvarya 1921 g. Razdel «Illiodor» [To the Secret Department of the All-Russian Extraordinary Commission. Report No. 2. Two-Week Information Report of the Tsaritsyn Provincial Extraordinary Commission on the Situation and Activities in the Province during the Period from January $15^{\text {th }}$ to $31^{\text {st }}$, 1921. Section 'Iliodor']. Tsentralnyy arkhiv Federalnoy sluzhby bezopasnosti Rossii [Central Archive of the Federal Security Service of Russia], F. 1, Op. 5, D. 390, 1. 111.

6. V SO VChK. Svodka № 20. Dvukhnedelnaya informatsionnaya svodka Tsaritsynskoy gubChK o polozhenii i svoey deyatelnosti v gubernii za vremya $\mathrm{s}$ 15-go po 30-e noyabrya 1921 g. Razdel «Iliodor» [To the Secret Department of the All-Russian Extraordinary Commission. Report No. 2. Two-Week Information Report of the Tsaritsyn Provincial Extraordinary Commission on the Situation and Activities in the Province during the Period from November $15^{\text {th }}$ to $30^{\text {th }}$, 1921. Section "Iliodor"]. Gosudarstvennyy arkhiv Volgogradskoy oblasti [State Archive of the Volgograd Region], F. R-37, Op. 2, D. 12, 1. 94.

7. V SO VChK. Svodka № 22. Dvukhnedelnaya informatsionnaya svodka TSaritsynskoy GubChK o polozhenii i svoey deyatelnosti v gubernii za vremya s 1 -go po 15-e noyabrya 1920 g. Razdel «Dukhovenstvo» [To the Secret Department of the All-Russian Extraordinary Commission. Report No. 2. Two-Week Information Report of the Tsaritsyn Provincial Extraordinary Commission on the Situation and Activities in the Province during the Period from November $1^{\text {st }}$ to $15^{\text {th }}, 1920$. Section 'Clergy']. Tsentralnyy arkhiv Federalnoy sluzhby bezopasnosti 
Rossii [Central Archive of the Federal Security Service of Russia], F. 1, Op. 4, D. 241, 11. 49-50.

8. Goltsev E. «Revolyutsioner sprava». Istoriya ieromonakha Iliodora [Revolutionary on the Right. History of Hieromonk Iliodor]. Nedelya (Moskva) [Week (Moscow)], 1990, no. 26, p. 10.

9. Dokladnaya zapiska byvshego zaveduyushchego SO VCHK M. I. Latsisa na imya predsedatelya VChK F. E. Dzerzhinskogo ot 3-4 dekabrya 1920 g. o politike VCHK v religioznom voprose [Memorandum of the Former Head of the Secret Department of the All-Russian Extraordinary Commission M. I. Latsis, Addressed to the Chairman of the Cheka F. E. Dzerzhinsky of December 3-4, 1920 on the Policy of the Cheka in the Religious Issue]. Tsentralnyy arkhiv Federalnoy sluzhby bezopasnosti Rossii [Central Archive of the Federal Security Service of Russia], D. R-33149, 11. 71-72.

10. Dokladnaya zapiska zaveduyushchego SO VChK T. P. Samsonova na imya predsedatelya VChK F. E. Dzerzhinskogo ot 4 dekabrya 1920 g. o politike VChK v religioznom voprose [Memorandum of the Head of the Secret Department of the All-Russian Extraordinary Commission T. P. Samsonov, Addressed to the Chairman of the Cheka F. E. Dzerzhinsky of December 4, 1920 on the Policy of the Cheka in the Religious Issue]. Rossiyskiy gosudarstvennyy arkhiv sotsialno-politicheskoy istorii [Russian State Archive of Social and Political History], F. 76, Op. 3, D. 196,11. 4-4.

11. Zhiv kurilka [The Smoker Is Alive]. Borba (organ Tsaritsynskogo gubkoma RKP (b) $i$ gubispolkoma) [Borba (Body of the Tsaritsyn Provincial Committee of the Russian Communist Party (Bolsheviks) and of the Provincial Executive Committee of the Soviets)], 1923, 21 February.

12. Zaverennaya mashinopisnaya kopiya pisma Iliodora, snyataya 14 avgusta 1921 g. [A Certified Typewritten Copy of Iliodor's Letter, Made on August 14, 1921]. Gosudarstvennyy arkhiv Rossiyskoy Federatsii [State Archive of the Russian Federation], F. R-130, Op. 5, D. 1030, 1. 6.

13. Zapisi tekstov vystupleniy Iliodora (Tsaritsyn, 24 aprelya, 1 iyunya, 19 avgusta 1921 g.) [Records of Iliodor's Speeches (Tsaritsyn, April 24, June 1, August 19, 1921)]. Gosudarstvennyy arkhiv Rossiyskoy Federatsii [State Archive of the Russian Federation], F. A-353, Op. 4, D. 399, 11. 21, 24, 32, 33.

14. Zapiska kursantki Kommunisticheskogo unta im. Ya. M. Sverdlova V. Rukavtsovoy na imya V.I. Lenina ot 15 iyunya $1921 \mathrm{~g}$. s informatsiey o tom, chto ona peredala v Priemnuyu Sovnarkoma RSFSR pismo Iliodora i ozhidaet otveta (esli takovoy budet) [A Note from the Female Student of the Communist University named after J. M. Sverdlov V. Rukavtsova, Addressed to V. I. Lenin of June 15, 1921 with Information that She Had Handed over the Letter of
Iliodor to the Reception of the Council of People's Commissars of the RSFSR and Is Waiting for an Answer]. Gosudarstvennyy arkhiv Rossiyskoy Federatsii [State Archive of the Russian Federation], F. R-130, Op. 5, D. 1030, 1. 3.

15. Izyatie i dukhovenstvo [The Confiscation and the Clergy]. Borba (organ Tsaritsynskogo gubkoma RKP (b) i gubispolkoma) [Borba (Body of the Tsaritsyn Provincial Committee of the Russian Communist Party (Bolsheviks) and of the Provincial Executive Committee of the Soviets)], 1922, 10 May.

16. Iliodorovshchina [Iliodorovshchina (The Time of Iliodor)]. Borba (organ Tsaritsynskogo gubkoma RKP (b) i gubispolkoma) [Borba (Body of the Tsaritsyn Provincial Committee of the Russian Communist Party (Bolsheviks) and of the Provincial Executive Committee of the Soviets)], 1928, 30 September.

17. Krapivin M.Yu. Deyatelnost S. M. Trufanova (byvshego ieromonakha Iliodora) v Sovetskoy Rossii (1918-1922 gg.) v svyazi s formirovaniem gosudarstvennoy politiki v otnoshenii Pravoslavnoy Tserkvi [Activities of S. M. Trufanov (Former Hieromonk Iliodor) in Soviet Russia (1918-1922) in Connection with the Formation of State Policy towards the Orthodox Church]. Vestnik tserkovnoy istorii (Moskva), 2011, no. 1/2 (21/22), pp. 137-159.

18. Lenin V.I. Predlozheniya k proektu postanovleniya Plenuma TsK RKP (b) o punkte 13 programmy partii (18 maya $1921 \mathrm{~g}$.) [Proposals for a draft resolution of the Plenum of the Central Committee of the Russian Communist Party on paragraph 13 of the party program (May 18, 1921)]. V.I. Lenin. Polnoe sobranie sochineniy: v 55 t. T. 54. Pisma. Noyabr 1921 - mart 1923 [Complete Works. In 55 vols. Vol. 54. Letters. November 1921 -March 1923]. Moscow, Politizdat Publ., 1970. XVI, 863 p.

19. Maykopskaya drama [Drama in Maikop]. Kommunist (organ Cherepovetskogo gubispolkoma $i$ gubkoma RKP (b)) [Kommunist (the Body of the Cherepovets Provincial Executive Committee of the Soviets and of the Provincial Committee of the Russian Communist Party (Bolsheviks)], 1919, no. 58, 27 April.

20. Nasledie Iliodora [The Legacy of Iliodor]. Borba (organ Tsaritsynskogo gubkoma RKP (b) $i$ gubispolkoma) [Borba (Body of the Tsaritsyn Provincial Committee of the Russian Communist Party (Bolsheviks) and of the Provincial Executive Committee of the Soviets)], 1922, 30 September.

21. Okunev N.P. Dnevnik moskvicha (19171924 gg.). V 2 kn. Kn. 1. 1917-1920 [Diary of a Muscovite (1917-1924). In 2 Books. Book 1. 19171920]. Moscow, Voennoe izd-vo, 1997. 319 p.

22. Ostavim bogov bez zhilploshchadi [Let's Leave the Gods without Housing Space]. Borba (organ Tsaritsynskogo gubkoma RKP (b) i gubispolkoma) 
[Borba (Body of the Tsaritsyn Provincial Committee of the Russian Communist Party (Bolsheviks) and of the Provincial Executive Committee of the Soviets)], 1929. 24 March.

23. Otnoshenie sekretarya Upravdelami Sovnarkoma RSFSR v Tsaritsynskiy gubispolkom № 10630 ot 15 avgusta 1921 g. s prosboy «soobshchit o deyatelnosti Illiodora v Tsaritsyne» [Letter from the Secretary of the Managing Director of the Council of People's Commissars of the RSFSR to the Tsaritsyn Provincial Executive Committee No. 10630 of August 15, 1921, Requesting 'to Report on Illidor's Activities in Tsaritsyn']. Gosudarstvennyy arkhiv Rossiyskoy Federatsii [State Archive of the Russian Federation], F. R-130, Op. 5, D. 1030, 1. 2.

24. Otnoshenie Tsaritsynskoy gubernskoy komissii po otdeleniyu tserkvi ot gosudarstva $\mathrm{v}$ VIII otdel Narkomyusta RSFSR № 32 ot 28 aprelya 1921 g. s prosboy dat rukovodyashchie ukazaniya po suti khodataystva «Khristianskogo pravoslavnogo kollektiva pri monastyrskom Svyatodukhovskom khrame g. Tsaritsyna» o predostavlenii im v polzovanie monastyrskogo khrama i trekh komnat v monastyrskom zdanii dlya organizatsii religioznoy sotsialnoy kommuny [Letter of the Tsaritsyn Provincial Commission for Church Separation from the State to the VIII Department of the People's Commissariat of Justice of the RSFSR No. 32 of April 28, 1921, with a Request to Give Guidance on the Petition by the Christian Orthodox Collective at the Church of the Monastery of the Holy Spirit (Tsaritsyn) on Granting Them the Right to Use a Monastery Church and Three Rooms in a Monastery Building for the Organization of a Religious Social Commune]. Gosudarstvennyy arkhiv Rossiyskoy Federatsii [State Archive of the Russian Federation], F. A-353, Op. 5, D. 237, 11. 64, 66-66.

25. Otchet Stalingradskogo gorodskogo soveta Soyuza voinstvuyushchikh bezbozhnikov o prodelannoy rabote s 15 yanvarya po 20 oktyabrya 1931 g. [Report of the Stalingrad City Council of the Union of Militant Atheists on the Work Done for the Period from January 15 to October 20, 1931]. Redkina O.Yu., Savina T.A., eds. Gosudarstvo $i$ religioznye organizatsii Nizhney Volgi i Dona v XX veke: sb. dok. i materialov; kat. kult. zdaniy [State and Religious Organizations of the Lower Volga and the Don in the $20^{\text {th }}$ Century: Collected Documents and Materials; Catalog of Religious Buildings]. Volgograd, Izdatel Publ., 2002, document no. 72, pp. 212-221.

26. Ocherki po istorii Volgogradskoy eparkhii Russkoy Pravoslavnoy Tserkvi [Essays on the History of the Volgograd Diocese of the Russian Orthodox Church]. Volgograd, Izdatel Publ., 2003. 368 p.

27. Perekrasivshiysya Iliodor [Iliodor Who Changed Color]. Izvestiia VTsIK [News of the All-Russia Central Executive Committee], 1919, no. 69, 30 March.
28. Pismo predsedatelya Tsaritsynskoy gubChK Karla Pogi na imya predsedatelya Tsaritsynskogo gubispolkoma I. M. Morozova № 225/s ot 11 (ili 14) sentyabrya 1921 g. s kharakteristikoy iliodorovskogo dvizheniya [Letter from the Chairman of the Tsaritsyn Provincial Extraordinary Commission Karl Poga, Addressed to the Chairman of the Tsaritsyn Provincial Executive Committee I. M. Morozov No. 225/s of 11 (or 14) September 1921 Describing the Iliodor's Movement]. Gosudarstvennyy arkhiv Volgogradskoy oblasti [State Archive of the Volgograd Region], F. R-37, Op. 2, D. 10, 1. 50.

29. Pismo S. M. Trufanova predsedatelyu Mossoveta L. B. Kamenevu ot 8 noyabrya 1919 g. s prosboy kompensirovat stoimost odezhdy i predmetov byta, otobrannykh u ego semyi «predstavitelyami Sovetskoy Vlasti» v Tsaritsyne v oktyabre-noyabre 1918 g. [Letter of S. M. Trufanov Addressed to the Chairman of the Moscow Council L. B. Kamenev of November 8, 1919 with a Request to Compensate the Cost of Clothing and Household Items Taken away from His Family by "Representatives of the Soviet Power " in Tsaritsyn in October-November 1918]. Rossiyskiy gosudarstvennyy arkhiv sotsialnopoliticheskoy istorii [Russian State Archive of Social and Political History], F. 323, Op. 2, D. 164, 11. 52-53.

30. Pismo S. M. Trufanova (predsedatelyu Mossoveta L. B. Kamenevu) ot 5 noyabrya 1919 g. s prosboy pomoch priobresti komplekt teploy odezhdy dlya nego samogo i chlenov ego semyi [Letter from S. M. Trufanov (Addressed to the Chairman of the Moscow Council L. B. Kamenev) of November 5, 1919 with a Request to Help Buy a Set of Warm Clothes for Him and His Family]. Rossiyskiy gosudarstvennyy arkhiv sotsialno-politicheskoy istorii [Russian State Archive of Social and Political History], F. 323, Op. 2, D. 164, 11. 50-51.

31. Pismo S. M. Trufanova v Prezidium Mossoveta ot 14 noyabrya 1919 g. s prosboy oplatit scheta na obshchuyu summu 11834 rub. 85 kop. za priobretennye im nosilnye veshchi [Letter from S. M. Trufanov to the Presidium of the Moscow Soviet of November 14, 1919 with a Request to Pay the Bills for a Total of 11,834 Rubles 85 kopecks for the Clothes He Bought]. Rossiyskiy gosudarstvennyy arkhiv sotsialno-politicheskoy istorii [Russian State Archive of Social and Political History], F. 323, Op. 2, D. 164, 1. 54.

32. Polnomochnomu predstavitelyu VChK [v] Privolzhskom voennom okruge (PRIVO). Svodka № 21. Dvukhnedelnaya informatsionnaya svodka Tsaritsynskoy gubChK o polozhenii i svoey deyatelnosti v gubernii za vremya s 16-go noyabrya po 1-e dekabrya $1921 \mathrm{~g}$. Razdel «Dukhovenstvo» [To the Plenipotentiary Representative of the All-Russian Extraordinary Commission [in] the Volga Military District. Report No. 21. Two-Week Information Report 
of the Tsaritsyn Provincial Extraordinary Commission on the Situation and Activities in the Province during the Period from November $16^{\text {th }}$ to December $1^{\text {st }}, 1921$. Section 'Clergy']. Gosudarstvennyy arkhiv Volgogradskoy oblasti [State Archive of the Volgograd Region], F. R-37, Op. 2, D. 12, 1. 108.

33. Polnomochnomu predstavitelyu VChK [v] PRIVO. Byulleten № 3. Dvukhnedelnyy informatsionnyy byulleten Tsaritsynskoy gubChK o polozhenii i svoey deyatelnosti v gubernii za vremya s 1-go po 15-e fevralya 1922 g. Razdel «Dukhovenstvo» [To the Plenipotentiary Representative of the AllRussian Extraordinary Commission [in] the Volga Military District. Bulletin No. 3. Two-Week News Bulletin of the Tsaritsyn Provincial Extraordinary Commission on the Situation and Activities in the Province during the Period from February $1^{\text {st }}$ to $15^{\text {th }}$, 1922. Section 'Clergy']. Gosudarstvennyy arkhiv Volgogradskoy oblasti [State Archive of the Volgograd Region], F. R-37, Op. 2, D. 18, 1. 65.

34. Polnomochnomu predstavitelyu VChK [v] PRIVO. Byulleten № 2. Dvukhnedelnyy informatsionnyy byulleten Tsaritsynskoy gubChK o polozhenii i svoey deyatelnosti v gubernii za vremya s 15-go po 31-e yanvarya 1922 g. Razdel «Illiodor» [To the Plenipotentiary Representative of the All-Russian Extraordinary Commission [in] the Volga Military District. Bulletin No. 2. Two-Week News Bulletin of the Tsaritsyn Provincial Extraordinary Commission on the Situation and Activities in the Province during the Period from January $15^{\text {th }}$ to $31^{\text {st }}$, 1922 . Section 'Iliodor']. Tsentralnyy arkhiv Federalnoy sluzhby bezopasnosti Rossii [Central Archive of the Federal Security Service of Russia], F. 1, Op. 6, D. 660, 11. 52-52.

35. Polnomochnomu predstavitelyu VChK [v] PRIVO. Byulleten № 1. Dvukhnedelnyy informatsionnyy byulleten Tsaritsynskoy gubChK o polozhenii i svoey deyatelnosti v gubernii za vremya s 1-go po 15-e yanvarya 1922 g. Razdel «Dukhovenstvo» [To the Plenipotentiary Representative of the AllRussian Extraordinary Commission [in] the Volga Military District. Bulletin No. 1. Two-Week News Bulletin of the Tsaritsyn Provincial Extraordinary Commission on the Situation and Activities in the Province during the Period from January $1^{\text {st }}$ to $15^{\text {th }}$, 1922. Section "Clergy"]. Tsentralnyy arkhiv Federalnoy sluzhby bezopasnosti Rossii [Central Archive of the Federal Security Service of Russia], F. 1, Op. 6, D. 660, 1. 49.

36. Postanovlenie Svyateyshego Patriarkha i Svyashchennogo Sinoda Pravoslavnoy Rossiyskoy Tserkvi ot 12/25 iyulya $1918 \mathrm{~g}$. po raportu obshchego blagochinnicheskogo sobraniya Tsaritsynskogo okruga Saratovskoy eparkhii ob opasnosti zakhvata Sergeem Trufanovym (pri sodeystvii mestnogo soveta) Svyato-Dukhovskogo monastyrya s tselyu sozdaniya $v$ nem kommunisticheskoy obshchiny [Decree of the Holy Patriarch and the Holy Synod of the Orthodox Russian Church of July 12/25, 1918 Concerning the Report of the General Deanery Meeting of the Tsaritsyn District of the Saratov Diocese about the Danger of Capture of the Holy Spirit Monastery by Sergey Trufanov (with the Assistance of the Local Council) with the Aim of Creating a Communist Community There]. Rossiyskiy gosudarstvennyy istoricheskiy arkhiv [Russian State Historical Archive], F. 831, Op. 1, D. 6, 1. 62.

37. Preprovoditelnoe pismo № 5404 ot 4 avgusta 1921 g. (k peresylaemomu pismu Iliodora) za podpisyu zaveduyushchego priemnoy Sovnarkoma RSFSR na imya Upravdelami Sovnarkoma RSFSR V. A. Smolyaninova [Covering Letter No. 5404 of August 4, 1921 (to Iliodor's Letter Sent), Signed by the Head of the Reception Room of the Council of People's Commissars of the RSFSR, Addressed for the Managing Director of the Council of People's Commissars of the RSFSR V. A. Smolyaninov]. Gosudarstvennyy arkhiv Rossiyskoy Federatsii [State Archive of the Russian Federation], F. R-130, Op. 5, D. 1030, 1. 4.

38. Proekt postanovleniya «Plenuma TsK RKP. po voprosu ob otnoshenii $\mathrm{k}$ narusheniyam p. 13 programmy i postanovke antireligioznoy propagandy», podgotovlennyy sekretarem TsK Em. Yaroslavskim [Draft Resolution of 'The Plenum of the Central Committee of the Russian Communist Party on the Violations of Paragraph 13 of the Program and on the Organization of Anti-Religious Propaganda', Prepared by the Secretary of the Central Committee Em. Yaroslavsky]. Rossiyskiy gosudarstvennyy arkhiv sotsialno-politicheskoy istorii [Russian State Archive of Social and Political History], F. 89, Op. 4, D. 127, 11. 1-6.

39. Proekt postanovleniya «Plenuma TsK RKP. po voprosu ob otnoshenii $\mathrm{k}$ narusheniyam p. 13 programmy i postanovke antireligioznoy propagandy», s pometami V. I. Lenina (18 maya 1921 g.) [Draft Resolution of 'The Plenum of the Central Committee of the Russian Communist Party on the Violations of Paragraph 13 of the Program and on the Organization of Anti-Religious Propaganda' with the Marks of V. I. Lenin (May 18, 1921)]. Rossiyskiy gosudarstvennyy arkhiv sotsialno-politicheskoy istorii [Russian State Archive of Social and Political History], F. 2, Op. 1, D. 18763, 11. 1-2.

40. Protokol zasedaniya Ogrbyuro TsK RKP (b) № 71 ot 26 sentyabrya 1921 g. P. 7. Utverzhdenie postanovleniya Plenuma TsK RKP (b) po voprosu o narusheniyakh punkta 13 programmy i o postanovke antireligioznoy propagandy [Protocol of the Meeting of the Organizational Bureau of the Central Committee of the Russian Communist Party (Bolsheviks) No. 71 of September 26, 1921. Item 7. Approval of the 
Resolution of the Plenum of the Central Committee of the Russian Communist Party (Bolsheviks) on the Violations of Paragraph 13 of the Program and on the Organization of Anti-Religious Propaganda]. Rossiyskiy gosudarstvennyy arkhiv sotsialnopoliticheskoy istorii [Russian State Archive of Social and Political History], F. 17, Op. 112, D. 310, 1. 15.

41. Protokoly zasedaniya plenuma TsK RKP (b) ot 18 maya 1921 g. P. 7. O provedenii v zhizn p. 13 programmy partii (ob otnoshenii partii k chlenam RKP, vypolnyayushchim tserkovnye obryady) [Protocols of the Meeting of the Organizational Bureau of the Central Committee of the Russian Communist Party (Bolsheviks) of May 18, 1921. Item 7. On the Implementation of Paragraph 13 of the Party Program (on the Party's Attitude Towards the Russian Communist Party's Members, Performing Church Ceremonies)]. Rossiyskiy gosudarstvennyy arkhiv sotsialno-politicheskoy istorii [Russian State Archive of Social and Political History], F. 17, Op. 2, D. 65, 11. 1, 9, 17, 20-20.

42. Protokol zasedaniya Prezidiuma VChK ot 1 aprelya 1919 g. P. 10 [Protocol of the Meeting of the Presidium of the All-Russian Extraordinary Commission of April 1, 1919. Item 10]. Tsentralnyy arkhiv Federalnoy sluzhby bezopasnosti Rossii [Central Archive of the Federal Security Service of Russia], F. 1, Op. 3, D. 3, 1. 4.

43. Protokol № 6 zasedaniya Tsaritsynskoy gubernskoy komissii po otdeleniyu tserkvi ot gosudarstva s predstavitelyami gubChK i Zhilishchnogo otdela Tsaritsynskogo gubispolkoma ot 10 aprelya 1921 g. P. 5. Zayavlenie «Khristianskogo pravoslavnogo kollektiva» pri monastyrskom Svyatodukhovskom khrame g. Tsaritsyna s prosboy predostavit im v polzovanie monastyrskiy khram i tri komnaty $\mathrm{v}$ monastyrskom zdanii dlya organizatsii religioznoy sotsialnoy kommuny [Protocol No. 6 of the Meeting of the Tsaritsyn Provincial Commission for the Church Separation from the State with Representatives of the Provincial Extraordinary Commission and the Housing Department of the Tsaritsyn Provincial Executive Committee of April 10, 1921. Item 5. Petition by the Christian Orthodox Collective at the church of the Monastery of the Holy Spirit (Tsaritsyn) on Granting Them the Right to Use the Monastery Church and Three Rooms in the Monastery Building for the Organization of a Religious Social Commune]. Redkina O.Yu., Savina T.A., eds. Gosudarstvo i religioznye organizatsii Nizhney Volgi i Dona v XX veke: sb. dok. i materialov; kat. kult. $z$ daniy [State and Religious Organizations of the Lower Volga and the Don in the $20^{\text {th }}$ Century: Collected Documents and Materials; Catalog of Religious Buildings]. Volgograd, Izdatel Publ., 2002, document no. 19, pp. 111-112.
44. Protokol № 9 ekstrennogo zasedaniya Tsaritsynskoy gubernskoy komissii po otdeleniyu tserkvi ot gosudarstva ot 23 aprelya 1921 g. P. 1. «Pismennoe zayavlenie ieromonakh[a] Iliodora»o predostavlenii emu vozmozhnosti publichnogo vystupleniya [Protocol No. 9 of the Emergency Meeting of the Tsaritsin Provincial Commission for the Church Separation from the State of April 23, 1921. Item 1. 'A Written Statement by Hieromonk Iliodor' about Giving Him the Opportunity to Speak Publicly]. Gosudarstvennyy arkhiv Volgogradskoy oblasti [State Archive of the Volgograd Region], F. R-122, Op. 1, D. 544, 11. 37-37.

45. Redkina O.Yu. Iliodor v Sovetskoy Rossii: 1918 1922 gg. [Iliodor in Soviet Russia: 1918-1922]. Strezhen: nauchnyi ezhegodnik [Strezhen: Scientific Yearbook]. Volgograd, Izdatel Publ., 2000, no. 1, pp. 164-169.

46. Sobstvennoruchnye zapisi predsedatelya VChK F. E. Dzerzhinskogo o vydache denezhnykh summ na spetsialnye raskhody («Kassa k 17/X 1919 g.») [The Handwritten Notes of the Chairman of the AllRussian Extraordinary Commission F. E. Dzerzhinsky on the Issue of Sums for Special Expenses (Cash Balance for October 17, 1919")]. Rossiyskiy gosudarstvennyy arkhiv sotsialno-politicheskoy istorii [Russian State Archive of Social and Political History], F. 76, Op. 3, D. 73, 1. 1.

47. Ferro M. Nikolay II [Nicholas II]. Moscow, Mezhdunarodnye otnosheniya Publ., 1991. 350 p.

48. Khodataystvo gruppy grazhdan posledovateley S. M. Trufanova v Tsaritsynskiy sovet rabochikh, soldatskikh, krestyanskikh i kazachyikh deputatov ot 3 iyunya $1918 \mathrm{~g}$. s prosboy predostavit zdaniya Svyato-Dukhovskogo monastyrya dlya organizatsii zemledelcheskoy kommuny na religioznykh nachalakh [The Petition of a Group of Citizens - Followers of S. M. Trufanov to the Tsaritsynskyi Council of Workers, Soldiers, Peasants and Cossack Deputies of June 3, 1918, with the Request to Provide the Buildings of the Monastery of the Holy Spirit for the Organization of an Agricultural Commune on a Religious Basis]. Gosudarstvennyy arkhiv Volgogradskoy oblasti [State Archive of the Volgograd Region], F. R-71, Op. 1, D. 144, 11. 12-14.

49. Tsirkulyarno-informatsionnoe pismo VChK № 3 ot 1 yanvarya $1920 \mathrm{~g}$. Razdel «V chem dolzhna sostoyat nasha rabota po chasti dukhovenstva» [Circular-Information Letter of the All-Russian Extraordinary Commission No. 3 of January 1, 1920. Section 'What Should Our Work with the Clergy Consist of?']. Tsentralnyy arkhiv Federalnoy sluzhby bezopasnosti Rossii [Central Archive of the Federal Security Service of Russia], F. 1, Op. 4, D. 155, 11. 10-10.

50. Yaroslavskiy Em. Doklad na zasedanii Plenuma TsK RKP (b) ot 18 maya 1921 g. po voprosu o narusheniyakh punkta 13 programmy i o postanovke 
М.Ю. Крапивин. Бывший иеромонах Илиодор (Труфанов) в планах ВЧК по внесению раскола в ряды ПРЦ

antireligioznoy propagandy [Report at the Meeting of the Plenum of the Central Committee of the Russian Communist Party (Bolsheviks) of May 18, 1921 on the Violation of Paragraph 13 of the Program and on the
Organization of Anti-Religious Propaganda]. Vestnik agitatsii $i$ propagandy (Moskva) [Bulletin of Agitation and Propaganda (Moscow)], 1921, no. 19 (15 September), pp. 26-28.

\section{Information about the Author}

Mikhail Yu. Krapivin, Doctor of Sciences (History), Professor of Institute of History, Saint Petersburg State University, Universitetskaya Emb., 7/9, 199034 Saint Petersburg, Russian Federation, m.krapivin@spbu.ru, mihailkrapivin61@yandex.ru, https://orcid.org/0000-0002-5199-3319

\section{Информация об авторе}

Михаил Юрьевич Крапивин, доктор исторических наук, профессор Института истории, Санкт-Петербургский государственный университет, Университетская наб., 7/9, 199034 г. СанктПетербург, Российская Федерация, m.krapivin@spbu.ru, mihailkrapivin61@yandex.ru, https://orcid.org/ 0000-0002-5199-3319 